\section{KNEE ARTHROPLASTY IN RHEUMATOID ARTHRITIS}

Sir,

It was interesting to read the article by Kristensen et al in your November 1992 issue entitled 'Long-term results of total condylar knee arthroplasty in rheumatoid arthritis' (1992; 74B:803-6). We draw your attention to some errors in Table III in which the percentages in each group do not match the numbers.

We would also like to discuss the relatively high rate of deep infection reported, one case of delayed infection and four of late infection (Table IV). The latter were presumably haematogenous in origin (Laskin 1990; Kristensen 1992), but may have resulted from organisms implanted at the time of surgery (Tooms 1992). Low-grade infection may be related to ineffective antibiotic prophylaxis. The authors state that they used oral methicillin from the time of operation until the third postoperative day. Methicillin is unstable in gastric acid when administered orally (Neu 1990) and inadequate serum concentrations of methicillin at the time of incision may have contributed to their deep infections.

We consider that the authors' use of oral methicillin as a prophylactic antibiotic for total knee arthroplasty is inappropriate.

C. L. TSAI, MD, PhD

T. K. LIU, MD, PhD

Department of Orthopaedic Surgery

National Taiwan University Hospital

Taipei, Taiwan

Republic of China.

Kristensen O, Nafei A, Kjaersgaard-Andersen P, Hvid I, Jensen J. Longterm results of total condylar knee arthroplasty in rheumatoid arthritis. J Bone Joint Surg [ Br] 1992; 74-B:803-6.

Laskin RS. Total condylar knee replacement in patients who have rheumatoid arthritis: a ten-year follow-up study. J Bone Joint Surg [Am] 1990; 72-A :529-35.

Neu HC. Penicillins. In : Mandell GL, Douglas RG Jr, Bennett JE, eds. Principles and practice of infectious diseases. 3rd ed. New York, etc: Churchill Livingstone, 1990:239.

Tooms RE. Arthroplasty of ankle and knee. In: Crenshaw AH, ed. Campbell's operative orthopaedics. Vol. 1, 8th ed. St Louis: MosbyYear Book Inc, 1992:425.

Author's reply:

As regards the error in Table III, we sent a correction to the Editor's office, but this was not fully implemented (corrected Table III on page $665-\mathrm{Ed}$ ).

Concerning the oral administration of prophylactic antibiotics and our late infection rate our regretful answer is that the statement which we gave on page 803 was incorrect. We actually used intravenous methicillin at the time of induction of anaesthesia and continued intravenous administration three times daily until the patient could accept oral dosage (usually 24 hours after surgery). Oral treatment then continued to give a total of 72 hours of antibiotic prophylaxis.

\section{A. NAFEI, MD}

Herluf Trollesgade 7C, st

DK-8200 Áarhus N

Denmark.

\section{LOCKED NAILING OF FRACTURES}

Sir,

I would like to comment on one aspect of the paper in the July 1992 issue by Robinson et al entitled 'Locking nailing of humeral shaft fractures' (1992; 74-B:558-62).

The authors have pointed out that the use of radiography to locate the exact position of the proximal locking screw is difficult, and a locking hole can easily be missed. If, however, the drill bit is left in place and the guide wire is reinserted it is possible to feel the drill bit and confirm that it is within the nail. This procedure can be repeated for the second screw provided that the most distal hole is locked first. The technique saves radiation exposure and has had no failures in our hands. The same method can be used for locking nails at other sites.

A. K. VARSHNEYA, FRCS Ed

Hospital for Orthopaedic and Accident Surgery

Agra, India.

Robinson CM, Bell KM, Court-Brown CM, McQueen MM. Locked nailing of humeral shaft fractures: experience in Edinburgh over a two-year period. J Bone Joint Surg [Br] 1992; 74-B:558-62.

\section{Author's reply:}

Thank you for asking me to comment on Dr Varshneya's letter. We have used the technique that he describes and find it of value for determining the position of the proximal locking screws in humeral nailing. Clearly, we should have used the method more often in our series! I am grateful to Dr Varshneya for describing it and would encourage its use by other surgeons.

C. M. COURT-BROWN, MD, FRCS Ed(Orth)

Princess Margaret Rose Orthopaedic Hospital

Edinburgh, UK.

\section{PROPHYLACTIC ANTIBIOTIC IN KNEE ARTHROPLASTY}

Sir,

In their brief report in the January 1993 issue (1993; 75-B:1578) entitled 'Regional prophylactic antibiotic in knee arthroplasty' Mr Hoddinott and Mr Lovering have established that for knee arthroplasty improved antibiotic levels can be achieved and maintained by regional administration. They do not, however, mention the risk of venous thrombosis from the irritant solution. They gave a $750 \mathrm{mg}$ dose of cefuroxime in $100 \mathrm{ml}$ of water, presumably using this dilute solution to minimise the possibility of thrombosis. We have attempted to reduce this risk and decrease the volume of the injection by injecting $600 \mathrm{IU}$ of heparin into the foot vein before giving a $750 \mathrm{mg}$ dose in $20 \mathrm{ml}$ of water.

A. G. MUIRHEAD, FRCS Ed(Orth), MRCP

A. CAMPBELL, FRCS

Department of Orthopaedic Surgery

The Ayr Hospital

Ayr, UK.

Hoddinott C, Lovering AM. Regional prophylactic antibiotic in knee arthroplasty. J Bone Joint Surg [Br] 1993; 75-B:157-8.

\section{Author's reply:}

We appreciate the concern regarding the risk of venous thrombosis expressed by Mr Muirhead and Mr Campbell. The introduction of heparin before antibiotic injection may be logical and it would be interesting to see the result of a controlled trial to evaluate the risk of antibiotic injection and whether or not heparin would be protective against venous thrombosis in this situation.

We considered a trial of regional intravenous heparin infusion as a primary method of prophylaxis against thrombosis, but the logistics of such a trial were discouraging. We see no value in reducing the injection volume, as the dilution factor may in itself be protective, but more importantly we feel that a high-volume injection is necessary to achieve adequate perfusion with antibiotic.

\section{HODDINOTT, FRCS, FRCS Ed \\ Morriston Hospital}

Morriston

Swansea, UK. 